2019 TheoLogica

An International Journal for Philosophy of Religion and Philosophical Theology

S. I. THE SON OF GOD

DOI: https://doi.org/10.14428/thl.v2i3.2313

\title{
Oneness Pentecostalism, the Two-Minds View, and the Problem of Jesus's Prayers
}

\author{
SKYLAR D. MCMANUS \\ Regent University \\ skylmcm@mail.regent.edu
}

\begin{abstract}
Even thirty years after Thomas Morris wrote The Logic of God Incarnate, there are some claims that Morris makes that require examination in analytic Christology. One of those claims is a concession that Morris gives to modalists near the end of the book, where he says that the two-minds view he has defended can be used to provide a consistent modalistic understanding of Jesus's prayer life. This view, he says, blocks the inference from the fact that Jesus prays to the Father to the additional claim that Jesus and the Father are numerically distinct. I argue that Oneness Pentecostals can appropriate central concepts from The Logic of God Incarnate as Morris suggests, and further that this means Oneness Pentecostals should abandon the claim that Jesus believes he just is the Father. Once Oneness Pentecostals abandon this claim, they can give a possible explanation of how it is that Jesus relates to the Father in prayer even though he just is the Father.
\end{abstract}

Keywords: Oneness Pentecostalism, modalism, prayer, Thomas Morris, Christology

Even thirty years after Thomas Morris wrote The Logic of God Incarnate, there are some claims that Morris makes that require examination in analytic Christology. As a case in point, consider a concession that Morris makes to unitarian modalists near the end of the book, where he says that the "two-minds" view that he has defended can work in their favor. ${ }^{1}$ His concession comes after he raises an argument like the following: Jesus has a prayer life and understands himself in relation to the Father. If so, then prayer involves a "two-termed relation" (Morris 1986, 209). But this two-

\footnotetext{
${ }^{1}$ An anonymous reviewer points out that one might consider certain forms of modalism as species of Trinitarianism. Be that as it may, I take it that Morris's point does not apply to these views. So I have called the modalist views I think Morris has in mind "unitarian" in order to rule out potential Trinitarian ones. Hereafter, when I refer to "modalism" I am referring to non-Trinitarian views.
} 
termed relation means that Jesus relates to the Father in prayer, which implies that Jesus and the Father are two persons. ${ }^{2}$ In other words, the claim is that if Jesus prays to the Father, then Jesus and the Father are numerically distinct. ${ }^{3}$ Morris responds:

I should point out, however, that the two-minds view of Christ can be taken to block this common inference. For it seems possible to hold, on the two-minds view, that in prayer and other spiritual exercises engaged in by Jesus the earthly mind or consciousness was relating itself consciously to the overarching, properly divine mind, both of which, on the view developed, belong to one and the same divine person (Morris 1986, 209).

Morris claims that on modalism and the two-minds view, Jesus can pray in a truly human way without requiring that Jesus and the Father are numerically distinct persons. ${ }^{4}$ That is, given Morris's two-minds view, it is possible for Jesus to pray to the Father and yet be numerically identical to the Father. ${ }^{5}$ His view allows Jesus's prayer life to be "understandable on a fully modalist conception of deity" (Morris 1986, 209).

Contemporary Oneness Pentecostalism accepts the "fully modalist conception of deity" that Morris has in mind. In this paper I will explore how Oneness Pentecostals can appropriate key ideas in The Logic of God Incarnate to avoid absurdities like Jesus consciously praying to himself. By using Gethsemane as one exemplary case of Jesus praying to the Father, I will argue that Oneness Pentecostals should accept that, while Jesus is praying to the Father, he does not believe (in his human range of

${ }^{2}$ Morris brings up this point by saying that the one who holds to Social Trinitarianism can make this argument to get the conclusion that Jesus and the Father are (in a predicative sense) both God. But I think that others who believe that Jesus is solely God's exalted human Messiah (e.g., biblical unitarians) can make this same argument. So the way I have summarized this argument is consonant with what Morris thinks is a Social Trinitarian point, but does not require Social Trinitarianism to make that point.

${ }^{3}$ i.e., $\mathrm{Pj} \rightarrow(\mathrm{j} \neq \mathrm{f})$, where Px means " $x$ is praying to the Father at time $t$." Certain views of concretecompositional Christology hold that Jesus Christ (the $j$ in the prior conditional) is not a Person. On these views, simply modify the $j$ in the antecedent and consequent to read "the divine Person who is (in a predicative sense) Jesus Christ." I discuss different concrete-compositional models of the Incarnation in section 2.

${ }^{4}$ I will use a lower-case $p$ in "person" or "persons" when the referent includes (or may include) non-divine persons. And I will use an upper-case $P$ in "Person" or "Persons" when the referent includes only divine Persons. However, I will not modify any quotations from other authors to fit this convention. Also, all Persons are persons, but the converse is not the case.

${ }^{5}$ i.e., it is possible that the antecedent of $\mathrm{Pj} \rightarrow(\mathrm{j} \neq \mathrm{f})$ is true while the consequent is false. 
consciousness) that he is numerically identical to the Father. ${ }^{6}$ If the Oneness Pentecostal denies this claim, and yet holds that Jesus believes that he just is the Father, she no longer has a consistent Christology. (I will call this the "Problem of Jesus's Prayers.") Given my main contention, I go on to show that Oneness Pentecostals can use some claims from Morris's two-minds view to block the "common inference" from Jesus's prayer life to the additional claim that Jesus and the Father are numerically distinct persons.

With that said, there are two points of clarification I need to make. First, the solution that I offer to the Problem of Jesus's Prayers is merely a possible one; I am not asserting that it is true. Second, I say "some claims" because I think all that is needed to make my proposal work is that (1) Jesus has two ranges of consciousness and (2) Morris's concepts of a full-accessible belief-set and of epistemic possibility are workable ones. Morris's two-minds view as a whole has received objections in the literature, both as to its implausibility and as to its impossibility. ${ }^{8} \mathrm{I}$ am only using the necessary elements of Morris's two-minds view to make my case, and I do not think that my argument relies on Morris's entire view. ${ }^{9}$

This paper contains five sections. In the first section, I will explain how Morris solves what I will call the "Problem of Tempting God." I will then consider a number of desiderata for Oneness Pentecostal Christology and show that, no matter what model of the Incarnation Oneness Pentecostals adopt, the arguments I offer in the rest of the paper still work (with appropriate modifications). After this, I explain that there is an inconsistency that follows from Oneness Pentecostal claims about Christ. In the fourth section I argue that the best way to avoid this inconsistency is to

${ }^{6}$ Jason Dulle (2018a, 2018b, 2018c) also suggests that it is possible, if Jesus has two minds or consciousnesses, that Oneness Pentecostals can have a coherent view of Jesus's prayers and his relationship with the Father. But he does not use ideas from Morris's two-minds view as a way to defend his discussion, and he does not draw out the implications of the view. What Dulle provides is a suggestion, and I provide the substance to his suggestion.

7 In this paper I will use "just is" as a shorthand for "is numerically identical to." Both of these phrases are equivalent to using the "is" of identity, or placing two subjects on either side of the equals $(=)$ sign.

${ }^{8}$ As to the implausibility of the view, see Bayne (2001) and Stump $(1989,221)$. For its impossibility, see Stump $(1989,222)$ and Loke $(2014,47)$. Also consult Arcadi $(2016 b)$ for a response to Loke's arguments.

${ }^{9}$ For example, Morris's view is what Arcadi (2018a, 179n75) calls an "abstract-relational" view. As I argue below, I think that David K. Bernard assumes a concrete nature view of Christ's human nature, rather than an abstract nature view. This means that, by definition, the Oneness Pentecostal does not need to assume Morris's entire framework in order to make the proposal that I offer in this paper. 
abandon the claim that Jesus believes he just is the Father. This also provides the solution to the Problem of Jesus's Prayers.

\section{Morris's Solution to the Problem of Tempting God}

After Morris explains a number of metaphysical distinctions in the earlier chapters of The Logic of God Incarnate, he considers whether or not Jesus could have a truly human experience of temptation. The problem at the heart of Morris's exploration is the intuition that, if Jesus is God the Son Incarnate and as such cannot sin, then it seems like Jesus cannot experience temptation. This is because the experience of temptation seems to presuppose the ability to sin. So, it seems like Jesus both has the ability to sin (by being tempted) and the inability to sin (since God's necessary goodness precludes his sinning). Both of those things, so the argument goes, cannot be said of Jesus at the same time (Morris 1986, 138-140). This is the "Problem of Tempting God" (hereafter, "PTG").

To solve the PTG, Morris works with his previously discussed suggestion that Jesus has two minds: one human and one divine. ${ }^{10} \mathrm{He}$ does not use the term "minds" to refer to persons (Morris 1986, 102n19). Instead, Jesus's two minds are something like two "noetic structures" (Morris 1986, 103). And each mind is associated with its own range of consciousness. ${ }^{11}$ How Jesus's two minds relate is important. The human mind, according to Morris, is "contained by" the divine mind, but the divine mind is not contained by the human mind. As a result, there is an "asymmetrical accessing relation" from the divine mind to the human mind, where the divine mind can access all the contents of the human mind, but the reverse is not true (Morris 1986, 103). Each mind contains its own beliefs and experiences, and yet both belong to the same subject: Jesus himself.

10 The fact that Jesus just is God the Son on Morris's view does not preclude the Oneness Pentecostal from using the central concepts of the two-minds view. As I say in section 2, all the Oneness Pentecostal who accepts a species of Model A compositional Christology needs to say is that the divine Person who is (in a predicative sense) Jesus Christ has two ranges of consciousness.

${ }^{11}$ I am using "is associated with" ambiguously here. That's because I am unsure about whether Morris uses "mind" and "range of consciousness" synonymously. At times it seems like Morris assumes each mind has a range of consciousness, and at other times it seems like he assumes that a mind just is a range of consciousness. When I explain how the Oneness Pentecostal can use Morris's central claims, I will drop the use of the term "mind" altogether. This leaves open the possibility that Jesus has two minds and two ranges of consciousness, or that Jesus has one mind and two ranges of consciousness. I will also simply refer to each range of consciousness as the "divine consciousness" or "human consciousness," rather than the more laborious "divine (or human) range of consciousness." 
As a result, Jesus is able to have two concurrent sets of experiences that are relativized to each of his respective minds. The two-minds view, then, allows Morris to deny that if Jesus is tempted, then it must be broadly metaphysically possible that he sin. All that is needed for Jesus to experience temptation is that it is "epistemically possible" to Jesus that he sin. Morris says that

Jesus could be tempted to sin just in case [i.e., if and only if] it was epistemically possible for him that he sin. If at the times of his reported temptations, the full accessible belief-set of his earthly mind did not rule out the possibility of his sinning, he could be genuinely tempted, in that range of consciousness, to sin. But this could be so only if that belief-set did not contain the information that he is necessarily good (Morris 1986, 148).

As long as it seems to Jesus (relative to the beliefs in his human mind) that it is possible for him to sin at any time that he is tempted, this is sufficient for Jesus to truly experience temptation. The PTG is therefore resolved.

It is important to be as clear as possible about the central terms that Morris uses to solve the PTG, since they will be of consequence below. When he explains how it is epistemically possible to Jesus for him to sin, Morris uses the following concepts:

Full Accessible Belief-set. The set of beliefs $B$ accessible in the mind $M$ of a conscious subject $S$ at a time $t$ which is sufficient to initiate action when beliefs in $B$ are accessed. ${ }^{12}$

Epistemic Possibility. At time $t$, a belief in proposition $P$ by a conscious subject $S$ is epistemically possible for $S$ if and only if, relative to $S^{\prime} s$ full accessible belief-set $B, B$ does not contain a subset that itself contains: ${ }^{13}$

(a) The belief that not- $P$, or

(b) The belief that not-possibly- $P$, or

(c) Beliefs that obviously demonstrate not- $P$ to $S$, or

(d) Beliefs that obviously demonstrate not-possibly-P to $S .{ }^{14}$

12 "A full accessible belief-set of a person at a time consists in all and only those beliefs which are accessible to a range of conscious thought and deliberation of that person at that time sufficient to support the initiation of action" (Morris 1986, 148).

${ }^{13} \mathrm{~A}$ "subset" here is meant to include either the entire belief-set $B$ (since any set is a subset of itself) or any proper subset of $B$.

14 "Very roughly ... some proposition $P$ is epistemically possible for some subject $S$ at a time $t$ just in case ... relative to a full accessible belief-set $B$ of $S$ at $t \ldots B$ neither contains nor self-evidently 
In another passage, Morris puts these concepts to use when he says, "On the twominds view, it can be held that within the beliefs naturally accessible to his earthly consciousness, it was epistemically possible for Christ that he sin. From his earthly point of view, his sinning was not logically ruled out" (Morris 1986, 149). Relative to Jesus's full accessible belief-set $B$ in his human mind, it is epistemically possible for Jesus to be tempted to sin because $B$ does not contain the proposition (or any propositions that would allow Jesus to infer) that he is necessarily good (or possibly necessarily good) and therefore incapable of sinning. I will return to the central concepts from this section when I present my arguments in sections 3 and 4 . Before then, I need to provide some frame of reference for what Oneness Pentecostals believe.

\section{Oneness Pentecostal Desiderata}

In what follows, I will explain some of the central claims that Oneness Pentecostals make about God and Jesus by using David K. Bernard as my main interpreter. This is not to say that his specific views are completely representative of all Oneness Pentecostal organizations (let alone all Oneness Pentecostals) worldwide. Nevertheless, I will do this for at least three reasons. First, Bernard is currently the General Superintendent of the United Pentecostal Church International (UPCI), which is perhaps the largest Oneness Pentecostal organization today (Bernard 2016, 42). ${ }^{15}$ Second, Bernard's works are widely available and accessible, which is not true of all the books that Oneness Pentecostals have published. Third, as a former member of the UPCI, I am most familiar with Bernard's works.

To begin with, Oneness Pentecostals hold to the firm conviction that there is only one divine Person. As Bernard claims, God is "absolutely one in numerical value" (2000b, 321). The claim that God is "absolutely one" is not meant to rule out the fact that God has many divine attributes - a fact that Bernard himself argues for at length (2000b, 23-40). Rather, it is meant to assert that (1) monotheism is true and (2) that

\footnotetext{
entails the denial of $P$, nor does $B$ contain or self-evidently entail propositions which seem to $S$ to show $P$ to be either false or impossible" (Morris 1986, 148). I render (a) through (d) more explicitly than Morris does in terms of beliefs because they are accessible contents in a full-accessible belief set. Whether or not epistemic possibility should be rendered in terms of belief rather than knowledge is debatable. See Kochiras (2006) and Huemer (2007) for two views.

15 Bernard's profile as the General Superintendent of the UPCI is available at https://www.upci.org/about/leadership/profile/david-k-bernard (accessed November 25, 2018).
} 
there are no other divine Persons than the divine Person who just is God himself. The claim that there are three eternally divine Persons, no matter how one understands it, is incorrect. ${ }^{16}$ This is why Bernard says, "Any plurality associated with God merely relates to attributes, titles, roles, manifestations, modes of activity, relationship to humanity, or aspects of God's self-revelation" (Bernard 1989, 2). There is no "plurality" of divine Persons in the one God.

With that being the case, Oneness Pentecostals recognize that they must explain why the Bible makes reference to God in three ways: as Father, Son, and Holy Spirit. The standard reply is that God reveals himself "as Father in creation, Son in redemption, and Holy [Spirit] in regeneration" (Bernard 2000b, 142). ${ }^{17}$ In other words, God becomes known to humanity, at different times in history, through his various "manifestations," "modes," or "roles." God's manifestations are ways that he relates to, or is known by, humanity.

Oneness Pentecostals are not committed to the view that God's manifestations are sequential. That is to say, Oneness Pentecostals do not typically claim that God becomes the Father at a time $t_{1}$, and then at a later time $t_{2}$ stops beings the Father to become the Son, and then at a later time $t_{3}$ stops being the Son to become the Holy Spirit. Bernard says that some understand Sabellius's view this way, but that this "does not reflect the beliefs of older modalism or of modern Oneness" $(2000 \mathrm{~b}, 240)$. It is entirely possible, on the Oneness view, for some (or all) of God's manifestations to occur simultaneously. For example, God can manifest himself as the Son and also speak at the Son's baptism. As Bernard explains, at Jesus's baptism the voice is "only another manifestation of the omnipresent Spirit of God" (2000b, 176). This is incomprehensible (and therefore uncharitable) if one attributes to Oneness Pentecostalism the view that God's manifestations are sequential.

\footnotetext{
16 See Tuggy (2016) for views about the Trinity.

17 It is unclear whether some Oneness Pentecostals think that the Father is a divine Person or simply one of God's modes (or manifestations). In the quotation I give here, it sounds like the Father is only a mode. Bernard $(1989,8)$ also says that "The one God is the Father of creation, Father of the only begotten Son, and Father of believers." But if one takes the "is" in all three cases here to be predicating mere modes like "Father of creation" (etc.) to the one God, this is uncharitable. Bernard $(2000 b, 66-70 ; 1989,5)$ claims that Jesus is the Father Incarnate, which fails to make sense on this interpretation of him, since a mode or manifestation of a thing cannot become incarnate. He also explicitly says, "The phrase 'God the Father' is biblical and refers to God Himself (Galatians 1:1-4). God is the Father; He is not merely Father of the Son but the Father of all creation" (Bernard 2000b, 126). I take it that, on Bernard's view, "Father" is therefore a proper name for God himself and that the Father is a divine Person.
} 
With regard to its Christology, Bernard claims that "Oneness may be seen as compatible with the Christological formulation of the Council of Chalcedon, namely that Christ has two complete natures - deity and humanity - but is only one person" (2000a, 20). ${ }^{18}$ With Chalcedon, then, Oneness Pentecostals can accept that Christ is one Person with two natures. As such, Oneness Pentecostals seek to avoid Apollinarianism and Nestorianism. With regard to the latter, Bernard says that Oneness Pentecostals "do not embrace the error that Nestorius was accused of, namely, that Christ was two persons" $(1995,153)$. And regarding the former, he says that "Oneness scholars overwhelmingly reject" that Oneness Christology is Apollinarian (Bernard 2000a, 20).

It seems that all Oneness Pentecostals are committed to the conciliar claim that Jesus has two wills (i.e. dyothelitism). After all, Jesus prays in Luke 22:42, "not my will, but yours, be done." Jesus is praying to the Father in this passage, and he clearly predicates a will of the Father that is distinct from his own human will. Since the Father and the Son cannot be different divine Persons on Oneness theology, that means they must hold that Jesus, as the Father Incarnate, has two wills: a divine will and a human will. Bernard (2000b, 93) affirms dyothelitism by appealing to Luke 22:42 and John 6:38. But this affirmation notwithstanding, I think that Oneness Pentecostals must accept dyothelitism because of these passages. If the Oneness Pentecostal denies dyothelitism, she is committed to the idea that Jesus makes a false predication, either because it is false that Jesus has a human will, or because it is false that the Father has a divine will. Neither alternative is consonant with the biblical text.

Oneness Pentecostals use the terms "Jesus," "Son of God," and "Son" equivocally. Consider first the term "Son." Bernard explains that it "can refer to the human nature of Christ alone (as in 'the Son died') or to the union of deity and humanity (as in 'the Son shall return to earth in glory')" (2000a, 18). The same applies to the term "Son of God," since it "may refer to the human nature or it may refer to God manifested in flesh - that is, deity in the human nature" $(2000 \mathrm{~b}, 98)$. In other words, both "Son" and "Son of God" may refer either to Christ's human nature in particular, or to the Incarnation entirely (i.e., the Father plus his human nature plus the relation(s) between them). However, neither of these terms can refer to the Father-the divine Person who is incarnate-alone (Bernard 2000a, 18-19). On the other hand, "Jesus" can refer to the Father simpliciter or the Son, because "the one name of Matthew 28:19 must be Jesus" (Bernard 2000a, 25). And it can refer to the Son of God as well

${ }^{18}$ I will not alter quotations to fit the conventions that I stipulated in footnote 4 above. I also do not make it a practice to capitalize personal pronouns when used of God and Jesus. These conventions, when used, are original to the authors that I quote. 
(Bernard 2000b, 127). In order to maintain consistency, it seems that Bernard must say that "Jesus" can refer to the Son and the Son of God in both senses these terms carry. Now I need to say more about how Bernard understands Christ's human nature.

Following Alvin Plantinga (1999), one may distinguish the abstract nature view of Christ's human nature from the concrete nature view. ${ }^{19}$ On the abstract nature view, "the term 'human nature' denotes a property (or, if you like, group of properties)" such that one is human if and only if one has that property (or group of properties) (Plantinga 1999, 184). Applying this to Oneness Christology, for the Father to become incarnate means that he begins to exemplify a property (or set of properties) necessary and sufficient for his being truly human. On the concrete nature view, "the term 'human nature' denotes a concrete human being rather than a property," where "the thing denoted by 'human nature' and that gets assumed is a human being, a concrete object" (Plantinga 1999, 184). Another way to put this is that the Father becomes incarnate by assuming a "concrete particular, perhaps a human body, but, traditionally, a human body and human soul" (Crisp 2007, 41). It is possible on either view of Christ's human nature for the Father to become incarnate by either transforming, by entering into a particular relation with a concrete human object(s), or both. ${ }^{20}$

It seems to me that Bernard assumes a concrete-relational Christology. He says that the "humanity of Jesus, when viewed alone, theoretically had the capacity to sin" (Bernard 2000b, 96). Additionally, it is the case that "the humanity of Jesus is not eternal but was born in Bethlehem" (Bernard 2000b, 104). From prior quotations, it is also clear that Jesus's human nature can die. None of these things can be true of an abstract nature. And because Bernard denies that Jesus is "the transmutation of God into flesh" $(1994,29)$, it seems that he thinks that the Incarnation involves God entering into a relation with true humanity rather than God somehow transforming into a human.

One way to a achieve a concrete-relational Christology is to hold to compositional Christology. On compositional Christology, there is "a genuine unity, but a composite one, just as the human body itself is genuinely a single thing, but with

\footnotetext{
${ }^{19}$ For more on this distinction see Crisp (2007, 41-42), Hill (2011, 11-12), and Arcadi (2016a, 232234; 2018a, 155-160).

${ }^{20}$ See Hill (2011, 8-11) and Arcadi (2018a, 153-155). I say "or both" here in order to make room for Hill's $(2011,10)$ claim that Richard Swinburne's model of the Incarnation is both transformational and relational. Also, I say "or objects" to make room for the supposition that a concrete human nature includes both a human soul and human body.
} 
parts" (Hill 2011, 12). The concrete particulars involved in the Incarnation-the divine Person, the human body, and (perhaps) the human soul-somehow compose one thing. Following Thomas Flint (2011), one can distinguish between two families of compositional models. ${ }^{21}$ One way to do this is to ask this question: Does "Jesus Christ" (or simply "Christ") refer to a Person, or not? The "Model A" family entails that "Christ" does not refer to a Person. This is why Oliver Crisp opens the explication of his Model A view (he calls it the "Habitus" model) ${ }^{22}$ with the admission that "God the Son is not [numerically] identical to Christ, though God the Son and Christ's human nature together compose Christ" (2011, 47). Crisp's view is a mereological one, and he says that Christ "is a whole composed of the proper parts of God the Son and (the parts of) his human nature" (Crisp 2016, 97). But there is another way to understand why "Christ" does not refer to a Person. Katherin Rogers (2013) defends an "action composite" view of the Incarnation that is analogous to a boy playing a video game. This amounts to the Incarnation being like "a composite state of affairs composed of the concrete particulars [of the Word] and [a human nature], and also the features they exhibit, and the relations among them" (Rogers 2013, 254). Here "Christ" refers to a state of affairs, and no person can be numerically identical to a state of affairs. (Replace "the Word" and "God the Son" with "the Father" for these Model A views to work on Oneness Christology.) On the other hand, the Model T family holds that "Jesus Christ" refers to a Person. This is because the divine Person involved in the Incarnation takes on a human nature that is more like a proper part (or parts) of himself (Hill 2011, 13).

It is difficult to determine precisely how Bernard thinks the Incarnation "works." But on analysis, his view seems to fit best with a Model A compositional Christology ${ }^{23}$ Bernard says, "We can say the Son died but we cannot say the Father

${ }^{21}$ Strictly speaking, Flint's paper is about mereological models of compositional Christology. But his twofold schema can still apply to non-mereological compositional models, making these models further species within the genera of Model T and Model A (see Hill 2011, 12-14).

${ }^{22}$ An anonymous reviewer disputes Crisp's use of the "Habitus" label. Gordon (2016, 61n16) points out that, if one is speaking about the habitus view that Peter Lombard explains in Sentences III.6 (see Silano 2008, 24-31), Crisp's view is not that view. It seems to me that the difference here is over how literally one wants to press the "garment" (habitus) analogy, and I do not intend to defend Crisp's label as one that is apt.

${ }^{23}$ An anonymous reviewer presses an objection that Flint $(2011,81)$ raises, which Crisp $(2011,51)$ calls the "no-person objection." This reviewer also seems to think the Model A view, as I have explained it, commits the Oneness Pentecostal to Nestorianism. Neither of these objections affect my case. First, my arguments in sections 3 and 4 apply to any view of the Incarnation that the Oneness Pentecostal wants to adopt. If it turns out that the no-person objection goes through, or that the Model A view is unorthodox, so much the worse for Bernard (if I am right that his view is best 
died. The deity in the Son is the Father. Although we do not believe that the Father is the Son, we do believe that the Father is in the Son" (Bernard 2000b, 127; emphasis original). Surely Bernard does not mean that the Father is not the Son in a predicative sense of "is." That would mean that the predicate "Son" is not apt (i.e., is false) of the Father, and therefore false that the Father became incarnate. Rather, he must be denying that the Father is numerically identical to the Son. Here it is crucial to recall that Oneness Pentecostals equivocate on the term "Son." Bernard explicitly denies that the Father just is a particular human nature, for I have already pointed out that he says the Incarnation is not a "transmutation." This leaves only one option: Bernard is denying that the Father just is the Son in the sense of the Incarnation entirely, and therefore rejects the Model T view. Furthermore, Bernard claims that the Father exists beyond his human nature: "While Jesus walked this earth as a man, His Spirit [i.e., the Father] was still everywhere at the same time" (Bernard 2000b, 82). ${ }^{24}$ If Gordon $(2016,59-61,65)$ is right that Model $T$ views are not straightforwardly compatible with this kind of claim, then it seems most charitable to understand Bernard along Model A lines. ${ }^{25}$ In any case, Bernard leaves room for different explanations of the Incarnation. He says that the Bible "does not describe in detail how these two natures are united in the one person of Jesus Christ... Perhaps there is room for divergent views on this issue since the Bible does not treat it directly" (Bernard 2000b, 90).

The upshot of the foregoing discussion is the following: The arguments that I offer in sections 3 and 4 do not presuppose a particular view of Jesus's human nature, or a particular model of the Incarnation. In those arguments I assume, for the sake of clarity, that "Jesus Christ," "Jesus," and "Christ" (in the sense of the Incarnation

construed along Model A lines), but not for my case. Second, supposing one adopts a Model A view like the one Rogers (2013) puts forward, the no-person objection does not obviously apply. As she says, it is not surprising to say that Nick in "Nick Playing" shoots a non-playable character even though, strictly speaking, it is Nick's Character that does this (Rogers 2013, 262). In the same way, it seems right on Oneness Christology to say that the Father is responsible for the actions of Christ on this sort of Model A view. Finally, there are responses in the literature for handling the Nestorian objection. See Leftow (2002, 281-282), Crisp (2011, 56-60), Stump (2002, 208-209), and Marmodoro and Hill (2010, 483-486).

${ }^{24}$ Other Oneness Pentecostals seem to accept this as well. A committee of Oneness Pentecostals (chaired by Bernard) affirms the following: "While Jesus walked on earth as God Himself incarnate, the Spirit of God continued to be omnipresent" ("Oneness-Trinitarian Pentecostal Final Report, 20022007" 2008, 214).

${ }^{25}$ Here I am asserting that Bernard seems to at least assume what Gordon $(2016,1 \mathrm{n} 1)$ calls the "weak" version of the extra Calvinisticum. Furthermore, it is arguable that if the Oneness Pentecostal wants to claim that the Spirit of Jesus just is the Father (Bernard 200b, 131-133), and also that the Holy Spirit just is the Father (Bernard 2000b, 129-131), she must affirm some form of the extra Calvinisticum. 
entirely) refer to a Person. This of course fits directly with a Model T compositional Christology (or with a model of the Incarnation that uses the abstract nature view). If one were to opt for a Model A compositional Christology instead, one only needs to modify every instance of these terms to read "the divine Person who is (in a predicative sense) Jesus Christ" and the arguments still work. It is now necessary to turn to those arguments.

\section{Inconsistent Oneness Pentecostal Claims}

Oneness Pentecostals tend to stress the true humanity of Jesus Christ. They want to say that Christ's human nature is like ours, and they do so for a number of reasons. For Bernard, it is the case that no matter how "we define the essential components of humanity, Christ had them: flesh, body, soul, spirit, mind, [and] will" $(1994,18)$. Furthermore, Jesus was "God dwelling and manifesting Himself in true humanity, with everything humanity includes" (Bernard 1994, 19). He seems to think that this must be the case because otherwise Jesus does not qualify as our "kinsman redeemer." Bernard asks, "If we deny the humanity of Jesus, we encounter a problem with the concept of redemption and atonement. Not being fully human, could His sacrifice be sufficient to redeem us? Could He really be a true substitute for us in death? Could He truly qualify as our kinsman redeemer?" (2000b, 95). Jesus must have true humanity in the same way other humans do, otherwise he cannot be our savior.

Bernard and other Oneness Pentecostals have also affirmed that Jesus has truly human experiences and relationships. Between 2002 and 2007, the Society of Pentecostal Studies hosted dialogues between Oneness and Trinitarian Pentecostal committees in order to allow each group to come to a greater understanding of the other. Bernard chaired the Oneness committee. ${ }^{26}$ This is part of what his committee affirmed about Christ:

41. We affirm the genuine and complete humanity of Jesus. Christ's humanity means that everything we humans can say of ourselves, we can say of Jesus in his earthly life, except for sin. Moreover, in every way that we relate to God, Jesus related to God, except that he did not need to repent or be born again ("Oneness-Trinitarian Pentecostal Final Report, 2002-2007" 2008, 215; cf. Bernard 1999, 2-3).

26 That Bernard chaired this committee is affirmed by the Society of Pentecostal Studies (“Oneness-Trinitarian Pentecostal Final Report, 2002-2007" 2008, 204) and by Bernard (2016, 43n50). 
Bernard makes a similar affirmation elsewhere: "In every way that we humans can speak of our humanity and our relationship to God, so could Jesus, except for sin" (2000b, 88). If Jesus is truly human, then Jesus has truly human experiences and relationships. He knows "what it is like" to be a human.

With a nod to the prior block quotation, I will call the following claims, when conjoined, "Proposition 41" (or simply "P41"). From P41 we see that Oneness Pentecostals affirm something like these two claims:

P41(a). Whatever is true of a typical human nature is true of Jesus's human nature (in his earthly life), except that it is sinful.

P41(b). Whatever is true of the way a typical human relates to God is true of the way Jesus relates to God, except for truths about humans brought about by sin.

The problem with P41, understood as the above conjuncts, is that they are far too vulnerable to obvious objections. For example, P41(a) might lead one to conclude that because it is true that a typical human nature is not assumed by a divine Person, that therefore Jesus's human nature cannot be either. Likewise, one might conclude from P41(b) that because the typical human relationship with God includes the truth that the human is a created person, that therefore Jesus must be as well.

These objections can be handled, in a preliminary way, at least, by understanding P41 in the broader Oneness Pentecostal context. I have already showed that Oneness Pentecostals think that Jesus is the Father Incarnate, so they must affirm versions of P41(a) and P41(b) that are consistent with that claim. It is really the burden of the Oneness Pentecostal to state precisely what she means in P41(a) and P41(b). However, something like the following might be close, and will be sufficient for my purposes:

P41( $\left.\mathbf{a}^{*}\right)$. With regard to his human nature, Jesus is $F$ essentially if and only if:

(a) Jesus is $F$, and

(b) For any human subject $S$, (i) $S$ is $F$ and (ii) $S \neq$ Jesus, and

(c) $F$ is univocal, and

(d) "Jesus is $F$ " and "S is $F$ " are true merely in virtue of Jesus and $S$ having a human essence, respectively. ${ }^{27}$

\footnotetext{
${ }^{27}$ For what I am getting at here, see Pawl $(2018,931)$. This is only one way to modify P41(a), and I do not think Oneness Pentecostals must make the same modification or affirm the same underlying metaphysics.
} 
P41(b*). The state of affairs "Jesus relates to God" (call this "J") obtains if and only if:

(a) J obtains and

(b) For any human subject $S$, (i) the state of affairs "S relates to God" (call this " $H$ ") obtains and (ii) $S \neq$ Jesus, and

(c) $J$ and $H$ obtain under relevantly similar circumstances.

So construed, P41( $\left.\mathrm{a}^{*}\right)$ and $\mathrm{P} 41\left(\mathrm{~b}^{*}\right)$ avoid the obvious objections raised. Condition (d) of P41( $\left.\mathrm{a}^{*}\right)$ says that because Jesus and $S$ are human (i.e., have a human essence, or nature, respectively), there are certain predicates that are true of them simply because of what it means to be human (e.g., "rational"). If we take $F$ to mean "that which has a non-assumed human nature," it is not obvious, on condition (d) of $\mathrm{P} 41\left(\mathrm{a}^{*}\right)$, that this must be true of Jesus and $S$ simply because of what it means to be human. Regarding P41( $\left.\mathrm{b}^{*}\right)$, condition (c) does not say that the states of affairs $J$ and $H$ must obtain under identical circumstances; rather, it stipulates that they obtain under comparable ones. So it is not obvious on P41( $\left.\mathrm{b}^{*}\right)$ that $J$ and $H$ can comparably obtain only if Jesus is a created person.

It is also standard for Oneness Pentecostals to say that Jesus claims to be the Father in the Gospels. (This entails that Jesus believes that he just is the Father, otherwise it does not make sense to say he claims to be the Father.) Typically, they appeal to texts like John 8:58, John 10:30, and John 14:7-11 in order to show this. For example, John 14:9-11 "can be viewed as nothing less than the claim of Christ to be the Father manifested in flesh" (Bernard 2000b, 68). The Jews also understand that Jesus is claiming to be the Father Incarnate in John 8:58 and John 10:30 (Bernard $2000 \mathrm{~b}, 75-76$ ). These passages notwithstanding, Bernard states that it is probably the case that "from the earliest times of [Jesus's] human self-consciousness and memory His brain had some awareness of His divine identity and mission," and that it is incorrect to say that Christ was "unaware of His identity and mission until a certain time" (1986, 134-135). Such an idea is "strongly rejected" by Oneness Pentecostals (Bernard 2000a, 20-21).

David Norris also affirms that Jesus claims to be divine in the Gospel of John. The Jews rightfully understand Jesus's claim in John 8:58 "as a claim to be Yahweh" (Norris 2009, 67). And in John 10:30, "The Jews would not at all have thought that Jesus was claiming to be a second divine person. They were furious because they recognized He was claiming to be Yahweh" (Norris 2009, 104). If Norris is right, then Jesus believes he just is the Father at least at the times he makes these claims and 
thereafter. ${ }^{28}$ And if he wants to follow Bernard, Norris should say that Jesus believes this even prior to the time that he makes these claims.

If Oneness Pentecostals jointly affirm P41 and the claim that Jesus believes he just is the Father, then they no longer have a consistent Christology. To see why, consider P41 $\left(\mathrm{b}^{*}\right)$ again. It seems to be the case that $H$ obtains because it is epistemically possible to $S$ that $S$ is not numerically identical to God. ${ }^{29}$ Under typical circumstances, $S$ relates to God as though God were distinct from $S$. This condition is relevant because it is hard to see how $S$ truly relates to a distinct subject $S_{n}$ unless nothing rules out for $S$ that she is not numerically identical to $S_{n}$. The foregoing yields the following argument:

1. If $\mathrm{P} 41\left(\mathrm{~b}^{*}\right)$ is the case, then it is epistemically possible for Jesus (in his human consciousness) that he is not numerically identical to the Father.

2. P41 is the case.

3. Therefore, $\mathrm{P} 41\left(\mathrm{~b}^{*}\right)$ is the case. (From 2)

4. Therefore, it is epistemically possible for Jesus (in his human consciousness) that he is not numerically identical to the Father. (From 1, 3)

5. Jesus believes (in his human consciousness) that he just is the Father.

P41 is simply the conjunction of $\mathrm{P} 41\left(\mathrm{a}^{*}\right)$ and $\mathrm{P} 41\left(\mathrm{~b}^{*}\right)$, so the latter follows by simplification to give premise (3). I gave support for premise (5) above.

The following premise is also true:

6. Therefore, it is not epistemically possible for Jesus (in his human consciousness) that he is not numerically identical to the Father.

Reverse the definition of epistemic possibility in section 1 so that it applies to the proposition not- $P$ instead. The proposition "it is not the case that I am numerically identical to the Father" is not $-P$. For not- $P$ to be epistemically possible for Jesus, the negation of not- $P$ (i.e., not-not- $P$, or simply $P$ ) cannot be in Jesus's full-accessible belief set $B$. But from premise (5), it follows that $P$ is, in fact, in $B$. Therefore, not- $P$ is not epistemically possible to Jesus and premise (6) is true.

\footnotetext{
${ }^{28}$ That is, unless one wants to claim that after Jesus makes these claims he forgets (in his human consciousness) that he just is the Father by the time the Gospels record his experiences in Gethsemane and the Cross. But this would be both unwarranted by the biblical text and would be ad hoc.

${ }^{29}$ As I will point out in section 4, the Oneness Pentecostal can argue that it is not the case that Jesus must believe he is not numerically identical to the Father. Even though this occurs in the typical case, it does not occur in Jesus's case.
} 
If the understanding of $\mathrm{P} 41\left(\mathrm{~b}^{*}\right) \mathrm{I}$ have offered is close to what the Oneness Pentecostal wants to affirm, then P41 and premise (5) yield a contradiction and cannot both be true. That leaves open at least three options to Oneness Pentecostals. One is that they can deny that the epistemic possibility of a person's being nonidentical to God is a relevantly similar circumstance for $J$ and $H$ in P41( $\mathrm{b}^{*}$ ) both obtaining. This is, in effect, to affirm the antecedent of premise (1) and to deny that its consequent follows from condition (c) of P41 $\left(b^{*}\right)$, rendering (1) false. The other two options are to simply deny P41 (and therefore one or both of its conjuncts), or to deny premise (5). Since we have already seen Oneness Pentecostals affirm P41, it is charitable to assume that they will reject one of the two remaining premises. In my estimation, there are at least two reasons that Oneness Pentecostals should deny premise (5) instead of premise (1).

\section{The Problem of Jesus's Prayers}

The first reason Oneness Pentecostals should deny premise (5) is because it is plausible that Jesus's belief that he just is the Father precludes him from having some truly human experiences. Some distinctions from the philosophy of mind help to illuminate this point. As Bayne and Chalmers $(2003,27)$ point out, there does not seem to be any one thing that the term "consciousness" refers to. There are many different kinds of consciousness. Following Ned Block, they distinguish "phenomenal" from "access" consciousness. A particular mental state is phenomenal-conscious when there is "something it is like to be in that state" and that "involves some sort of subjective experience" (Bayne and Chalmers 2003, 28). And a particular mental state is access-conscious when, simply by having it, that state is "available for verbal report, for rational inference, and for the deliberate control of behavior" (Bayne and Chalmers 2003, 28)..$^{30}$ Beliefs are, by definition, access-conscious states. Furthermore, there is also "introspective" consciousness. Jedwab $(2011,171)$ says, "A mental state is introspective-conscious just if one introspects it. Introspection is a kind of attentive awareness of one's own mental states. Such an attentive act is itself phenomenal-conscious: there's something it's like to notice, focus on, or attend to one's mental states." Mental states that one

\footnotetext{
${ }^{30}$ Compare Jedwab (2011, 171): “So, as Chalmers has it, a mental state is access-conscious just if, by having it, its content is directly available for global control... So, for example, if I believe that there is an apple before me and I desire to grasp it, and I so act on the basis of my belief and desire, then my belief, desire, and act of will are all access-conscious." Also, Moreland and Craig $(2017,216)$ say that a mental state is access-conscious "if and only if that state is available for (1) guiding speech and verbal reports, (2) directing and controlling action and body movements, or (3) use in reasoning."
} 
introspects form the "phenomenal foreground," and those that one does not introspect form the "phenomenal background" (Jedwab 2011, 171).

A subject's phenomenal-conscious states are arguably affected by their accessconscious states (and vise versa). Bayne and Chalmers affirm this:

There is a close empirical connection between phenomenal consciousness and access consciousness. It is arguable that the two almost always go together empirically: when a state is phenomenally conscious, it is access-conscious, and vice versa. That is, when there is something it is like to be in a state, a subject can usually report the contents of the state and use it to directly guide reasoning and behavior. And when a subject can report the contents of a state and use it to directly guide reasoning and behavior, there is usually something it is like to be in that state (Bayne and Chalmers 2003, 28).

Likewise, Moreland and Craig affirm that five kinds of conscious states (including beliefs) all "exhibit phenomenal consciousness" (2017, 217).

Beliefs about who one is (i.e., one's numerical identity) are clear examples of access-conscious states that affect the experiences that subjects have. Suppose that $\mathrm{Al}$ is a person who consistently acts on his moral beliefs and that he always feels guilt when he does not act in a way that is consistent with them. Al thinks that stealing, grand theft auto, and trespassing are morally wrong. Also suppose that $\mathrm{Al}$ believes that he is numerically identical to himself (i.e., " $\mathrm{I}=\mathrm{Al}$ "). From the foregoing, it seems undeniable that there is "something it is like" to be Al. Even though $\mathrm{Al}$ is not always introspective-conscious of his belief that " $\mathrm{I}=\mathrm{Al}$," that belief clearly affects his phenomenal-conscious states. For example, he swipes a credit card connected to an account tied to his identity, drives a car with his name on the title, and lives in his home-all without any guilt that he is stealing, committing grand theft auto, or trespassing. It seems that $\mathrm{Al}^{\prime}$ s belief that " $\mathrm{I}=\mathrm{Al}$ " affects, to a very large extent, "what it is like" to be him. Al only seems to know "what it is like" to spend his own money, drive his own car, and live in his own home because he believes that "I = Al." If he did not have this belief, Al would be guilt-ridden, or he simply would not perform the actions that I have suggested.

If access-conscious states about one's identity can affect phenomenal-conscious states in typical cases like Al's, it seems that this can occur in Jesus's case. The accessconscious states that Jesus has (in his human consciousness) can plausibly affect his phenomenal-conscious states, especially the belief about his divine identity. Consider a paradigm case of this: Jesus praying to the Father in the Garden of Gethsemane. Other than on the Cross, it seems that Jesus is at the most vulnerable point in his adult life while he is in Gethsemane. If there is ever a place that Jesus 
has truly human experiences - or knows "what it is like" to be a human - it is there. Bernard affirms that Jesus's true humanity is on display in Gethsemane when he says, "If we do not accept that Jesus was fully human ... the description of His struggle and agony in Gethsemane" loses meaning (2000b, 94).

In the midst of Jesus's struggle in Gethsemane, he turns to the Father in prayer. Specifically, he prays multiple times that the Father would allow the "cup" to pass from him, if possible. It is clear that Jesus is dependent on the will of the Father for what is about to occur, and that he aligns his human will with the Father's divine will (Luke 22:42). Norris affirms that Mark's account of Jesus's prayer in Gethsemane is "intimate" $(2009,211)$. In fact, in Gethsemane "we share one of the most intimate moments of communion in the entire Gospel (Norris 2009, 118). It is where "Jesus prayed to the Father ... and received strength from Him to endure the crucifixion" (Bernard 2000b, 214). Yet Jesus prayed to the Father, not because his divine nature needed help, but because "the man" needed help (Bernard 2000b, 177). All of this is part of Jesus's true human experience of learning obedience to the Father (Bernard 2000b, 177; Norris 2009, 118).

All these affirmations are difficult to hold together if Jesus believes that he just is the Father. Consider what I will call the principle of "Truly Human Prayer" (hereafter, THP):

THP. Jesus has a truly human experience of prayer in Gethsemane only if, while he is praying to the Father, he is not conscious (in his human consciousness) that he just is the Father. ${ }^{31}$

For the sake of consideration, index Jesus's true human experience(s) of prayer in Gethsemane to the time(s) that he petitions the Father to let the cup pass from him. At the times of these petitions it is truly the case that Jesus depends on, is intimate with, and learns obedience to the Father in Gethsemane. One can consider each of these statements by substituting the phrase "relates to" in P41(b*) with "depends on," "is intimate with," and "learns obedience to." The resulting states of affairs $J$ and $H$ obtain under relevantly similar circumstances. Jesus experiences "what it is like" to pray to the Father and to relate to him in each of these ways. This is what it means to say he has a "truly human experience of prayer."

31 This is really a modification of premise (1) above, where "relates to God" in P41( $\left.\mathrm{b}^{*}\right)$ is substituted for "has a truly human experience of prayer." The two conditions after "only if" in THP fall under condition (c) of P41( $\left.b^{*}\right)$. So if premise (1) is false, then THP is false. If THP turns out to be true, then premise (1) will turn out to be true as well (by modus tollens). 
It still seems that each of these relations plausibly requires that it is epistemically possible to Jesus that he is not numerically identical to the Father. Another distinction will be helpful to make this point. In The Logic of God Incarnate, Morris distinguishes between a merely human subject and a fully human subject. He says, "An individual is merely human just in case [i.e., if and only if] it has all the properties requisite for being fully human (the component properties of human nature) and also some limitation properties as well" (Morris 1986, 65). These "limitation properties" are those that merely human subjects have in virtue of being created. But there is little reason to think that a fully human subject (i.e., Jesus) must also have these limitations (Morris 1986, 65-67). Suppose that for $S$ to be conscious that $S$ is not numerically identical to the Father is one such limitation. In the context of petitionary prayer, then, that means there are two kinds:

prayerm. A merely human subject $S$ prays to the Father and is not conscious that $S$ just is the Father.

prayerf. A fully human subject $S$ prays to the Father and is conscious that $S$ just is the Father.

The term "conscious" in THP, prayer , and $\operatorname{prayer}_{F}$ is purposefully ambiguous in order to account for phenomenal-, access-, and introspective-conscious states. No matter how one takes "conscious" in $\operatorname{prayer}_{M}$ and $\operatorname{prayer}_{F}$, it is either straightforwardly or plausibly the case that both result in qualitative differences and therefore in different prayer-experiences. If so, then the relations Jesus is supposed to have with the Father in Gethsemane do not obtain on prayer and $^{\mathrm{P}} 41\left(\mathrm{~b}^{*}\right)$. This means that Oneness Pentecostals cannot so easily deny premise (1) after all.

Suppose that "conscious" refers to phenomenal-conscious mental states. On this understanding, prayerm and prayer $_{F}$ simply do not result in qualitatively similar experiences. When $S$ prays on $\operatorname{prayer}_{M}, S$ experiences "what it is like" to petition the Father as though the Father were a distinct person from $S$. But on prayer, Jesus does not have this experience. Unlike $S$, Jesus does not experience "what it is like" to petition the Father as though the Father were numerically distinct from himself. That is simply what prayerm and prayer $F$ mean when "conscious" refers to phenomenalconscious states. If the same problem occurs when "conscious" refers to introspective- or access-conscious states, it seems that THP is more plausibly true than false.

The case for introspective-conscious states in prayerm and prayerf is fairly straightforward. If it is in the phenomenal foreground of Jesus's mind during prayer $F$ that he just is the Father, this still results in a qualitatively different phenomenal- 
conscious state than one that would occur on prayerm. That is because, on this understanding of prayer $_{F}$, Jesus is using what I will call "self-reference." For present purposes, to use self-reference is to use indexical terms or proper names to refer to oneself. Self-reference can occur when one uses an indexical term that is normally used to refer to other persons to refer to oneself instead. For instance, if I were to use the second-person indexical term "you" or some third-person indexical to refer to myself, I would be using self-reference. ${ }^{32}$

Any use of self-reference is either literal or non-literal. Consider first the literal use. For Jesus to use self-reference in prayer in a literal way would be for him to refer to the Father as "you" in the same way that one refers to another person as "you." That is to say, Jesus would be using "you" univocally with the way that "you" is normally used, which is to refer to someone else. ${ }^{33}$ But if Jesus uses self-reference like this, he is saying that he is someone other than himself, which is to deny the law of identity $(x=x)$. This means he is denying that he is identical to himself, which is absurd.

Now consider the non-literal use of self-reference. For Jesus to use non-literal self-reference would be for him to use the term "you" in a demonstrative, or perhaps deliberative, way. For example, I might use "you" in a demonstrative way by standing in front of a mirror, pointing at myself, and saying "you." Alternatively, I could use "you" in a deliberative way (e.g., "What do you think?"). In either of these nonliteral ways (or any others), the intimacy in Gethsemane that Norris attributes to Jesus simply disappears. If I do not experience any sort of intimacy with myself when I use demonstrative or deliberative self-reference (and I think it is clear that I do not), then I fail to see how Jesus does on prayer. $_{.}{ }^{34}$

32 The pronouns "you," "he," "she," and "it" can occur in Greek explicitly as personal pronouns, or implicitly as verb endings. It makes no difference on my understanding of self-reference which one of these Jesus utters when he prays.

${ }^{33}$ We might also consider what a literal, analogical use of an indexical term like "you" might mean as opposed to a literal, univocal use of the term. But I have omitted that discussion because I simply cannot make sense of what it might mean to say that an indexical term is used in an analogical way. If there is some sense to be made of this, this analogical use of the indexical might apply when God simpliciter uses such a term, but not to humans. In that sense, the argument that follows (which focuses on God Incarnate) still uses a valid distinction.

${ }^{34}$ One might also consider what I will call a "performative" use of self-reference. Here, Jesus uses the indexical "you" while introspective-conscious that he just is the Father in order to set an example for us. It has been suggested to me that one reason he might do this is because this is how he accesses power from his divine nature. In other words, Jesus does not act directly from his divine nature because he has to pray first for this to happen, just like we often have to pray before the Holy Spirit works in us. Setting aside how deceptive this sounds, this still results in qualitatively dissimilar 
The final way to understand "conscious" in prayerm and $\operatorname{prayer}_{F}$ is to suppose that it refers to access-conscious states. I have already given an analogy to the effect that beliefs about one's identity fundamentally shape one's phenomenal-conscious states. If the analogy I have provided is apt, it is hard to see how a belief about one's identity does not shape one's phenomenal-conscious states. So I see no reason to suppose that Jesus has the same experience of prayer on prayer $_{F}$ that a mere human on prayerm does, even if Jesus simply has the belief that he just is the Father and is not introspective-conscious of this belief at the time(s) he prays in Gethsemane. With that said, THP seems more plausibly true than false. Oneness Pentecostals should therefore give up premise (5) rather than say that epistemic possibilities about one's own identity are not relevant to condition (c) of $\mathrm{P} 41\left(\mathrm{~b}^{*}\right)$. Premise (1) seems to be true after all..$^{35}$

If THP is true and premise (5) is false, then it seems that there is another reason to accept that it is epistemically possible to Jesus that he is not numerically identical to the Father. It is simply that this allows him to experience a relationship with the Father in prayer, as Bernard and Norris seem to emphatically proclaim. By appropriating the solution to the Problem of Tempting God (i.e. the PTG) that Morris provides, Oneness Pentecostals can affirm the following: Jesus can relate to the Father in prayer only if it is epistemically possible for him that he is not numerically identical to the Father. If, during the times Jesus prays to the Father, the full accessible belief-set of his earthly range of consciousness does not rule out the possibility that he is not numerically identical to the Father, he can genuinely relate to the Father, in that range of consciousness, when he prays. But this can be so only if that belief-set does not contain the information that he is numerically identical to the Father. ${ }^{36}$ From this, it seems plausible that Jesus can both pray to the Father, and yet be numerically identical to the Father. It is no longer obvious that if Jesus prays

prayer-experiences on prayerm and prayerF. Like the other non-literal uses, I fail to see how this results in any sort of intimacy that Norris is fond of attributing to Jesus's prayers in Gethsemane.

${ }^{35}$ One might worry that I am jumping too quickly from Jesus failing to be conscious of the belief that he just is the Father to the epistemic possibility that he is not numerically identical to the Father. In response, the arguments I have offered apply for condition (c) of epistemic possibility (see section 1 ) as well. Regarding conditions (b) and (d), the belief that possibly- $P$ is consistent with the epistemic possibility that not $-P$. That is, so long as Jesus's belief that possibly- $P$ is not entailed by the belief that necessarily-P. (See figure 2.2 in Moreland and Craig [2017, 44].) No Oneness Pentecostals I know of say that Jesus believes that it is possible that he just is the Father and that it is possible that he is not. If they want to claim that instead, then they should still abandon premise (5).

${ }^{36}$ A portion of this paragraph is a parody of the final paragraph in Morris $(1986,148)$. 
to the Father he must be numerically distinct from the Father. ${ }^{37}$ Hence Morris's concession to modalists that I began this paper with seems to be a proper one.

The Problem of Jesus's Prayers, then, is this: If Oneness Pentecostals want to entertain a coherent (or even plausible) Christology, it must be the case that the ways that Jesus relates to the Father through his prayers in Gethsemane obtain in ways that are similar to how merely human subjects relate to the Father when they pray. To consistently hold to P41 and what it entails, Oneness Pentecostals should abandon the claim that Jesus believes he just is the Father. Instead, they should accept that it is epistemically possible to Jesus that he is not numerically identical to the Father. Since this allows Oneness Pentecostals to say that Jesus relates to the Father in all the ways they typically want to affirm, this seems to be a small price to pay for consistency.

One might object that the New Testament makes it seem as if Jesus believed that he was not the Father. ${ }^{38}$ Consider an example from the Gospel of John. Jesus says that "I testify about myself and the Father who sent me testifies about me" (John $8: 18$, NET). In context, the testimony that the Father and Jesus give is to the fact that Jesus is the "light of the world" (John 8:12). The Mosaic law that Jesus cites in John 8:17 says that two persons must serve as witnesses (Deuteronomy 17:6; cf. 19:15). ${ }^{39}$ If Jesus is able to say that he and the Father serve as witnesses in the way Deuteronomy requires, then it seems like he believes he can provide testimony about himself that is independent of the Father's testimony, which requires two persons. If Jesus believes that he is the Father in this passage, then Jesus seems to be at best asserting (unbeknownst to his audience) that he is able to testify about himself in two ways. But then it looks like the Pharisees' charge against Jesus in John 8:13 remains valid.

In response, the Oneness Pentecostal can say that, under the right circumstances, the New Testament is underdetermined with respect to the sort of access-conscious states that guide Jesus's behavior. The present objection amounts to the claim that

\footnotetext{
${ }^{37}$ That is, the two-minds (or rather, range of consciousnesses) solution I have offered allows the antecedent in $\mathrm{Pj} \rightarrow(\mathrm{j} \neq \mathrm{f})$ to be true while the consequent is false. Therefore, the conditional statement is false.

${ }^{38} \mathrm{My}$ thanks to two anonymous reviewers for raising this point. One reviewer raises this worry in terms of knowledge rather than belief. But I take it that if I address the problem from belief, this also addresses the problem from knowledge. After all, if $S$ knows that $P$, then $S$ believes that $P$. I have supplemented (and hopefully strengthened) the worry here by using some material I had placed elsewhere in a prior draft of this paper.

${ }^{39}$ I use "persons" here to allow this argument to work for the biblical unitarian. The argument here does not require Trinitarianism to go through. Obviously two Persons can serve as witnesses and hence fulfill this law.
} 
the belief that not $-P$ (i.e., "it is not the case that I am numerically identical to the Father") guides Jesus's behavior. However, epistemic possibilities can guide Jesus's behavior such that he performs the same actions if the following conditions are true: (1) Jesus neither believes $P$ (i.e., "I am numerically identical to the Father") nor its negation, and (2) Jesus does not have other beliefs that logically entail $P$ or its negation. If both of these conditions obtain, then neither $P$ nor its negation seem capable of guiding Jesus's behavior; they are not access-conscious states for him. But what can be access-conscious states for Jesus, in this case, are the epistemic possibilities for both $P$ and its negation, since both conditions guarantee that the definition of epistemic possibility I gave in section 1 obtains for both propositions.

Therefore, if Jesus neither affirms nor denies that he just is the Father, not $-P$ can be epistemically possible to Jesus and, on that basis, guide what Jesus says in John 8. It can still seem to Jesus (in his human consciousness) that the Father is a distinct source of testimony, and this can lead him to say what he does. Even if the Father were to audibly offer his testimony about Jesus to the Pharisees, it is reasonable to say that Jesus would form the true belief that the Father has testified about him without forming the belief that he just is the Father. Does this mean that Jesus is undecided about $P$ or its negation ${ }^{40}$ If by "undecided" one means that Jesus has been given reason to believe both $P$ and its negation and cannot find himself affirming either, then no. All the Oneness Pentecostal needs to suppose is that, in his omnipotence, God has brought it about that both of the conditions I suggested above are the case. This might occur because God has made it so that Jesus comes to form beliefs that preclude him from forming a positive belief about his divine identity (e.g., "The Father will reveal your true identity at the right time"), or perhaps because God simply governs things in such a way that Jesus never considers who he really is. So if one means by "undecided" that Jesus neither believes $P$ nor its negation, there does not seem to be a problem.

\section{Conclusion}

I have argued that Oneness Pentecostals can have a consistent view of Jesus's prayer life provided that they reject the claim that Jesus believes he just is the Father. They can do this by appropriating the idea that Jesus has two ranges of consciousness and by using a number of distinctions that Morris provides in The Logic of God Incarnate. Even though I have argued under the assumption that "Jesus" - in the sense of the Father plus his human nature plus the relation(s) between them - refers to a divine

\footnotetext{
${ }^{40}$ My thanks to an anonymous reviewer for raising this point.
} 
Person, my arguments still apply on other models of the Incarnation (with appropriate modifications) where this is not the case. Additionally, although Morris argues that Jesus's two ranges of consciousness are associated with two minds, what I have argued is also consistent with the fact that Jesus has one mind and two ranges of consciousnesses. ${ }^{41}$

The possible solution that I have argued for has serious ramifications for Oneness Pentecostal exegesis that will require further exploration. ${ }^{42}$ For one thing, if I am correct that THP is more plausibly true than false, then the proof-texts that Oneness Pentecostals typically use to show that Jesus claims to be the Father can no longer be understood in this way. These include passages like John 8:19-27, John 8:58, John 10:30, and John 14:9 (see Bernard 2000b, 68, 75-76). For another, Hebrews 7:25 and Romans 8:34 say that Jesus intercedes for us, and Bernard (2000b, 181) accepts this. Presumably "intercession" here refers to a particular kind of prayer. If so, then THP (where "in Gethsemane" is indexed to some other time) still seems to apply and Jesus, even post-resurrection, is not conscious that he just is the Father.

In addition, it seems that Oneness Pentecostals must accept some sort of model of the Incarnation that allows Jesus to have two consciousnesses. Andrew Loke (2014) has extensively defended a one-mind (and one-consciousness) view of the Incarnation that also accepts dyothelitism (and I argued above that Oneness Pentecostals must affirm dyothelitism). ${ }^{43}$ But Loke admits that if the Logos is not aware of his divine identity as a fetus in Mary's womb, he cannot exercise free will. But this is untenable because "in those [fetal] stages he would be unable to freely choose to do otherwise ... and he would cease to be omnipotent" (Loke 2014, 129). Therefore, the Logos "would have to maintain a conscious awareness of his ability to freely choose to access his divine preconscious at all stages of his Incarnation" (Loke 2014, 129). To be aware of one's divine preconscious implies that one is conscious that one is fully divine, and therefore some divine Person or other. This can only be the Father on Oneness Pentecostal theology. But this denies THP, and therefore is not an option on Oneness Christology.

\footnotetext{
${ }^{41}$ For example, the Oneness Pentecostal might opt for the abstract nature view and use Richard Swinburne's (1994, 192-215; 2008, 39-52) "divided mind" model (or something like it) instead.

${ }^{42}$ An anonymous reviewer asks how, if my proposal is correct, texts like John 17:5 make sense on Oneness Pentecostalism. Again, I have not argued that my proposal is correct, or even that Oneness Pentecostalism is plausible. So, this is precisely the kind of next-step question I hope Oneness Pentecostals and their interlocutors will discuss because of what I have argued.

${ }^{43}$ For Loke's defense of the consistency between his one-consciousness view and dyothelitism, see Loke (2016) and Loke (2014, 52-64, 76-77).
} 
The doors are now wide open for Oneness Pentecostals to enter the discussion in analytic Christology. And if what I have argued holds ground, it is also an invitation for Oneness Pentecostals and their interlocutors to take a fresh look at Oneness Pentecostal Christology from all angles. Clarifying the issues that I have raised will clear away a lot of the confusion about Oneness Pentecostalism and will provide a clear starting point for further dialogue. Hopefully Oneness Pentecostals will take the time to clarify their Christology along the lines I have suggested. But with clarification comes more problems to solve. There are still plenty of problems in Christology that Oneness Pentecostals have not addressed yet.

\section{Bibliography}

Arcadi, James M. 2016a. "Kryptic or Cryptic? The Divine Preconscious Model of the Incarnation as a Concrete-nature Christology." Neue Zeitschrift für Systematische Theologie und Religionphilosophie 58, no 2: 229-243. https://doi.org/10.1515/nzsth2016-0014.

Arcadi, James M. 2016b. "Review of A Kryptic Model of the Incarnation." Journal of Analytic Theology 4: 459-463. https://doi.org/10.12978/jat.2016-4.090018001708a.

Arcadi, James M. 2018a. An Incarnational Model of the Eucharist. Cambridge: Cambridge University Press. https://doi.org/10.1017/9781108588560.

Arcadi, James M. 2018b. "Recent Developments in Analytic Christology." Philosophy Compass 13, no. 4: 1-12. https://doi.org/10.1111/phc3.12480.

Bayne, Tim. 2001. "The Inclusion Model of the Incarnation: Problems and Prospects." Religious Studies 37, no. 2: 125-141. https://doi.org/10.1017/S0034412501005558.

Bayne, Tim and David Chalmers. 2003. "What is the Unity of Consciousness?" In The Unity of Consciousness: Binding, Integration, and Dissociation, edited by Axel Cleeremans, 23-58. Oxford: Oxford University Press. https://doi.org/10.1093/acprof:oso/9780198508571.003.0002.

Bernard, David K. 1986. "Oneness Christology." In Symposium on Oneness Pentecostalism 1986, 119-145. Saint Louis: Word Aflame Press.

Bernard, David K. 1989. "The Oneness View of Jesus Christ." Paper presented at the Society of Pentecostal Studies. Fresno, CA. November 16-18.

Bernard, David K. 1994. The Oneness View of Jesus Christ. Hazelwood, MO: Word Aflame Press.

Bernard, David K. 1995. A History of Christian Doctrine, Volume One: The PostApostolic to the Middle Ages, A.D. 100-1500. Hazelwood, MO: Word Aflame Press. 
Bernard, David K. 1999. “The Word Became Flesh: Oneness Pentecostal Perspectives on the Incarnation." (Indexed by The Society of Pentecostal Studies as "Roundtable on Oneness-Trinitarian Pentecostal Dialogue. 1999.") Paper presented at The Society of Pentecostal Studies. Springfield, MO. March 11-13.

Bernard, David K. 2000a. Essentials of Oneness Theology. Hazelwood, MO: Word Aflame Press.

Bernard, David K. 2000b. The Oneness of God. Hazelwood, MO: Word Aflame Press. Bernard, David K. 2016. The Glory of God in the Face of Jesus Christ: Deification of Jesus in Early Christian Discourse. Journal of Pentecostal Theology Supplement Series 45. Blandford Forum: Deo Publishing.

Crisp, Oliver. 2007. Divinity and Humanity. Cambridge: Cambridge University Press. https://doi.org/10.1017/CBO9780511805332.

Crisp, Oliver. 2011. "Compositional Christology without Nestorianism." In The Metaphysics of the Incarnation, edited by Anna Marmodoro and Jonathan Hill, 4566. Oxford: Oxford University Press. https://doi.org/10.1093/acprof:oso/9780199583164.003.0003.

Crisp, Oliver. 2016. The Word Enfleshed: Exploring the Person and Work of Christ. Grand Rapids: Baker Academic.

Dulle, Jason. 2018a. "A Oneness View of Jesus' Prayers." Institute of Biblical Studies. Accessed November 25. http://onenesspentecostal.com/jesusprayers3.htm

Dulle, Jason. 2018b. "Avoiding the Achilles Heel of Trinitarianism, Modalistic Monarchianism, and Nestorianism: The Acknowledgement and Proper Placement of the Distinction Between Father and Son." Institute of Biblical $\begin{array}{lll}\text { Studies. } & \text { Accessed } & \text { November }\end{array}$ http://onenesspentecostal.com/ugstsymposium.htm

Dulle, Jason. 2018c. “Jesus' Prayers: It Doesn't Take Two Persons to Tango." Institute of Biblical Studies. Accessed November 25. http://onenesspentecostal.com/jesusprayerstango.htm

Flint, Thomas. 2011. "Should Concretists Part with Mereological Models of the Incarnation?" In The Metaphysics of the Incarnation, edited by Anna Marmodoro and Jonathan Hill, 67-87. Oxford: Oxford University Press. https://doi.org/10.1093/acprof:oso/9780199583164.003.0004.

Gordon, James R. 2016. The Holy One in Our Midst: An Essay on the Flesh of Christ. Minneapolis: Fortress Press. https://doi.org/10.2307/j.ctt1b3t7gp.

Hill, Jonathan. 2011. "Introduction." In The Metaphysics of the Incarnation, edited by Anna Marmodoro and Jonathan Hill, 1-19. Oxford: Oxford University Press. https://doi.org/10.1093/acprof:oso/9780199583164.003.0001. 
Huemer, Michael. 2007. "Epistemic Possibility." Synthese 156: 119-142. https://doi.org/10.1007/s11229-005-4782-8.

Jedwab, Joseph. 2011. "The Incarnation and Unity of Consciousness." In The Metaphysics of the Incarnation, edited by Anna Marmodoro and Jonathan Hill, 168185. Oxford: Oxford University Press. https://doi.org/10.1093/acprof:oso/9780199583164.003.0009.

Kochiras, Hylarie. 2006. "Belief Contexts and Epistemic Possibility." Principia 10, no. 1: $1-20$.

Leftow, Brian. 2002. "A Timeless God Incarnate." In The Incarnation: An Interdisciplinary Symposium on the Incarnation of the Son of God, edited by Stephen T. Davis, Daniel Kendall, and Gerald O'Collins, 273-299. Oxford: Oxford University Press. https://doi.org/10.1093/0199248451.003.0012.

Leftow, Brian. 2011. “The Humanity of God." In The Metaphysics of the Incarnation, edited by Anna Marmodoro and Jonathan Hill, 20-44. https://doi.org/10.1093/acprof:oso/9780199583164.003.0002.

Loke, Andrew Ter Ern. 2014. A Kryptic Model of the Incarnation. Burlington, VT: Ashgate Publishing Company.

Loke, Andrew Ter Ern. 2016. “On Dyothelitism Versus Monothelitism: The Divine Preconscious Model." Heythrop Journal LVII: 135-141. https://doi.org/10.1111/heyj.12073.

Marmodoro, Anna and Jonathan Hill. 2010. "Composition Models of the Incarnation: Unity and Unifying Relations." Religious Studies 46, no. 4: 469-488. https://doi.org/10.1017/S0034412510000119.

Moreland, J. P. and William Lane Craig. 2017. Philosophical Foundations for a Christian Worldview. 2nd edition. Downers Grove, IL: InterVarsity Press.

Morris, Thomas V. 1986. The Logic of God Incarnate. Ithica: Cornell University Press. Morris, Thomas V. (1989) 2009. “The Metaphysics of God Incarnate." In Oxford Readings in Philosophical Theology, Volume 1: Trinity, Incarnation, Atonement, edited by Michael Rea, 211-224. Oxford: Oxford University Press. Reprint, Notre Dame, IN: University of Notre Dame Press.

Norris, David S. 2009. I AM: A Oneness Pentecostal Theology. Hazelwood: Word Aflame Press Academic.

“Oneness-Trinitarian Pentecostal Final Report, 2002-2007." 2008. Pneuma 30: 203224.

Pawl, Timothy. 2016. In Defense of Conciliar Christology: A Philosophical Essay. Oxford: Oxford

Press. https://doi.org/10.1093/acprof:oso/9780198765929.001.0001. 
Pawl, Timothy. 2018. "Conciliar Christology and the Consistency of Divine Immutability with a Mutable, Incarnate God." Nova et Vetera 16, no. 3: 913-937.

Plantinga, Alvin. 1999. "On Heresy, Mind, and Truth." Faith and Philosophy 16, no. 2: 182-193. https://doi.org/10.5840/faithphil199916221.

Rogers, Katherin A. 2010. "Incarnation." In The Cambridge Companion to Christian Philosophical Theology, edited by Charles Taliaferro and Chad Meister, 95-107. Cambridge: Cambridge University Press.

Rogers, Katherin A. 2013. "The Incarnation as Action Composite." Faith and Philosophy 30, no. 3: 251-270. https://doi.org/10.5840/faithphil201330324.

Silano, Giulio, trans. 2008. Peter Lombard, The Sentences, Book 3: On the Incarnation of the Word. Mediaeval Sources in Translation 45. Toronto: Pontifical Institute of Mediaeval Studies.

Stump, Eleonore. 1989. "Review of The Logic of God Incarnate." Faith and Philosophy 6, no. 2: 218-223. https://doi.org/10.5840/faithphil19896218.

Stump, Eleonore. 2002. "Aquinas' Metaphysics of the Incarnation." In The Incarnation: An Interdisciplinary Symposium on the Incarnation of the Son of God, edited by Stephen T. Davis, Daniel Kendall, and Gerald O'Collins, 197-218. Oxford: Oxford University Press. https://doi.org/10.1093/0199248451.003.0009.

Swinburne, Richard. 1994. The Christian God. Oxford: Oxford University Press. https://doi.org/10.1093/0198235127.001.0001.

Swinburne, Richard. 2008. Was Jesus God? Oxford: Oxford University Press.

Tuggy, Dale. 2016. "Trinity." The Stanford Encyclopedia of Philosophy. Accessed November 25. https://plato.stanford.edu/entries/trinity/

Published Online: January 14, 2019 